\title{
An Object Lesson: Strada's House in Vienna
}

Though we cannot attribute any executed project in Vienna to Strada on the basis of incontrovertible evidence, there was one building of which he certainly must have made the designs. Moreover here he certainly also closely supervised its execution, because he was not only its architect, but also its patron. When Strada had come to court, he had immediately brought his family and household with him, clearly intending to settle in Vienna, where he soon acquired a plot of ground on which to build himself a house. By the autumn of 1562 he indicates, in a business letter to the French Ambassador, Bernardin Bochetel, Bishop of Rennes, that this was one of his chief occupations at the time:

As to me and my family, we are all well; and I have become the complete philosopher, and I am always at home and attend to having built my little house. ${ }^{1}$

The reference to a 'small' house might be explained by a humanist conceit of modesty. But probably it refers to a house we know Strada at a later date possessed in St. Ulrich, a suburb of Vienna just outside the walls opposite the Hofburg. This may well be the house he had built soon after his arrival in Vienna, mentioned in his letter to Bochetel.

The house we know that Strada did eventually build for himself certainly was not small, but he acquired its site only after 1563, when in the Hofquartierbücher it is still indicated as 'Herren von Prag behausung. Freyhaus'. It is indicated as 'h. von Prag' on Bonifaz Wolmut's carefully measured plan of Vienna of 1547 [Fig. 7.1]..$^{2}$ It stood inside the city walls, in the close vicinity of the Hofburg, at the end of the Vorderen Schenkenstrasse, the present Bankgasse. It was the last house before the huge bulk of the Löwelbastei, which stood more or less on the location of the present Burgtheater [Figs. 7.2-7.3]. Only in the Hofquartierbücher of 1566 its owner is indicated as '507. Jacob Strada. Das haus hat vor deren von Prag haus gehaissen. Freyhaus'. ${ }^{3}$

1 DOC. 1562-10-21.

2 Camesina $1856-1858$.

3 The Hofquartierbücher are discussed and abstracted in Birk 1869 (the Strada house p. 124125), and Camesina 1881 (p. 21). But possibly Strada already leased the house in the Schenkenstrasse by 1562 and began to convert it even before he definitely acquired it. 

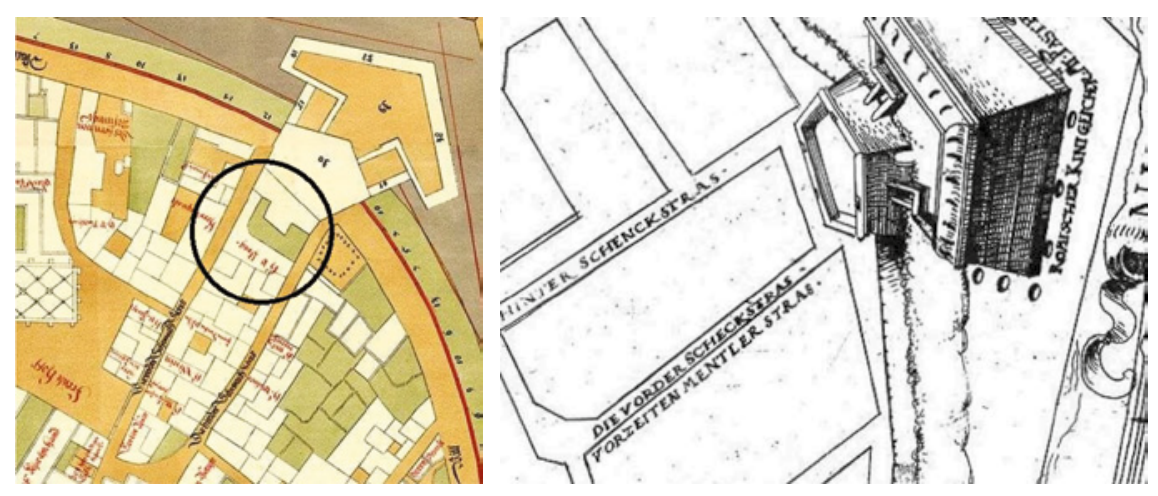

FIGURE 7.1 Bonifaz Wolmut, plan of Vienna, 1547 (copy from the nineteenth century). It indicates the house of the ' $\mathrm{H} . \mathrm{v}$ Prag', top centre, just before the Löwelbastei (nr 30 ).

FIGURE 7.2 Augustin Hirschvogel, plan of Vienna, 1547, detail of the same location.

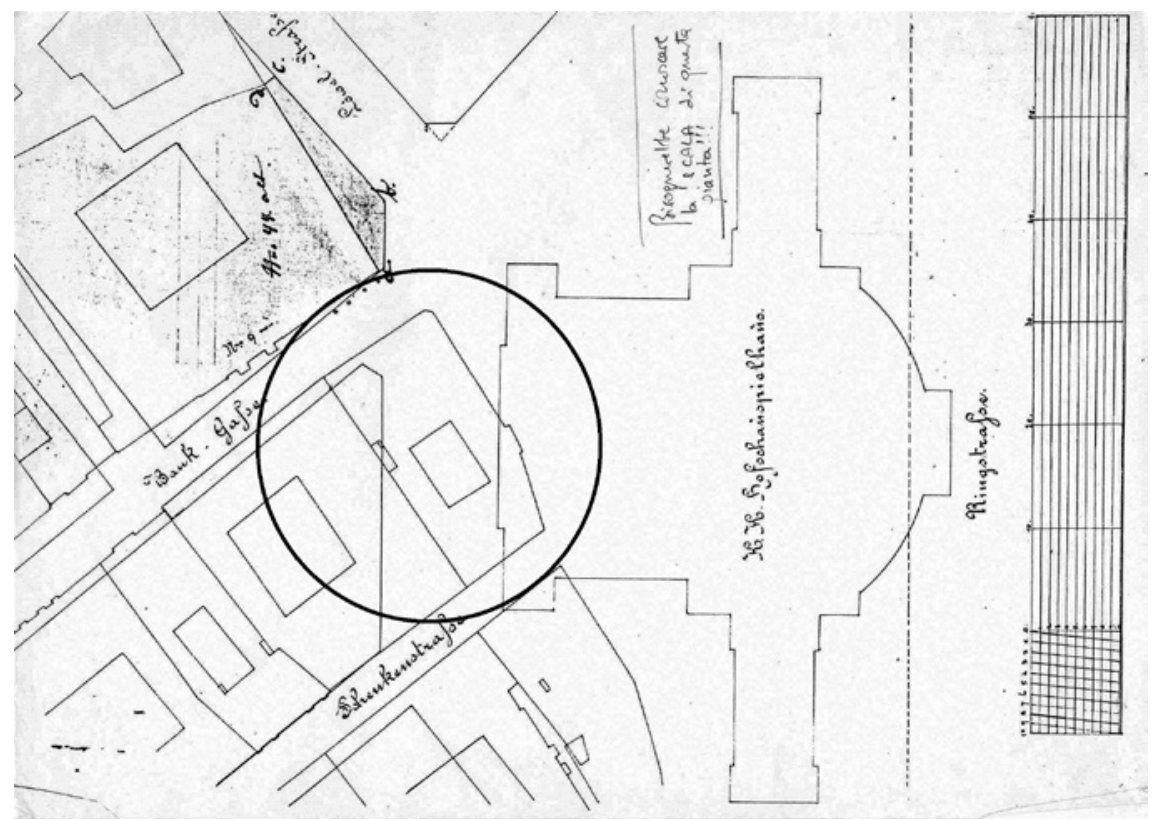

FIGURE 7.3 The position of Strada's house as seen in a drawing of the urban planning of the Ringstrasse: at right the K.K. Hofschauspielhaus—now the Burgtheater-slightly overlaps the Strada house.

That Strada could acquire this ample house in the best neighbourhood of Vienna may be due to the death of his father, which occurred sometime in 1563 or $1564 .{ }^{4}$ The fact that he could acquire it, tear it down and build a completely

4 His stepmother was engaged in arranging the heritage in 1564, DOC. 1564-oo-oo. 
new house in its place testifies to his wealth at the time; it certainly also testifies to his ambition and to his aristocratic pretensions. Close to the Hofburg and to the Landhaus in the Herrengasse - this was the meeting place of the Stände, the Estates of Lower Austria-the Schenkenstrasse counted many aristocratic dwellings. Opposite Strada's house, for instance, on the spot of the present Stadtpalais Liechtenstein, was that of Don Francisco Lasso de Castilia, Queen Maria's steward, and next to him on the same side of the street he had as his neighbours Juan Manrique de Lara and Christoph von Teuffenbach. ${ }^{5}$

All these aristocratic dwellings were so-called 'Freyhäuser', which means that - unlike the homes of normal citizens - they were not subject to the billeting of members of the Imperial court, a heavy burden on Vienna householders. It should be noted that the possession of such a Freyhaus was a privilege generally restricted to the nobility and to religious establishments, which indicates that Strada's noble status was accepted in Vienna long before Maximilian II's patent of 1574 formally confirmed it. ${ }^{6}$ This privilege unfortunately implies that, in contrast to most non-noble dwellings of Vienna, Strada's house is not described in detail as to living spaces, stables, fireplaces and fixed inhabitants in the Hofquartierbücher, the registers kept by the Hofquartiermeister, the court official responsible for allocating available lodgings to court-personnel and arriving guests.

Strada's obvious desire to stress both his noble status and to draw attention to his erudite and artistic expertise was expressed in the design of his house. He probably was influenced by famous artist's houses he had known, such as those of Raphael [Fig. 7.14] and Giulio Romano in Rome, and those of Mantegna and of Giulio in Mantua [Fig. 7.4]. Certainly it was quite advanced compared to other houses in Vienna, and it made a great impression on foreign visitors. When Alfonso II d'Este, Duke of Ferrara, visited his prospective brother-in-law in the summer of 1565 , he went once or twice to Strada's house

5 Perhaps Juan Manrique de Lara y Mendoza, Maximilian's envoy to the Pope in 1562-63 (cf. Holtzmann 1903, pp. 429 and 445-451). Teuffenbach was a general and Maximilian's envoy in Constantinople, see below, Ch. 10.9.

6 Occasionally the privilege was extended to important courtiers who were not noble (cf. Spielman 1993). In Strada's case, however, there is no reason to doubt his noble status, which he had corroborated by documents sent from Mantua, and which Maximilian's patent explicitly confirms (DOC. 1574-12-27). Strada's marriage to Ottilie Schenk von Rosberg, last of an ancient line of noblemen from Franconia, would hardly have been possible had he not been accepted as a nobleman even in 1544. His sons Paolo and Ottavio were accepted as gentlemen of the chamber of Archdukes Rudolf and Ernest. Perhaps most striking example is that in 1574 Ottavio, supervising the printing of his father's book, bought for his own use a fur-lined mantle from Sigmund Feyerabend which this famous printer had been expressly forbidden to wear by the Frankfurt City Council (DOC. 1574-12-05). 


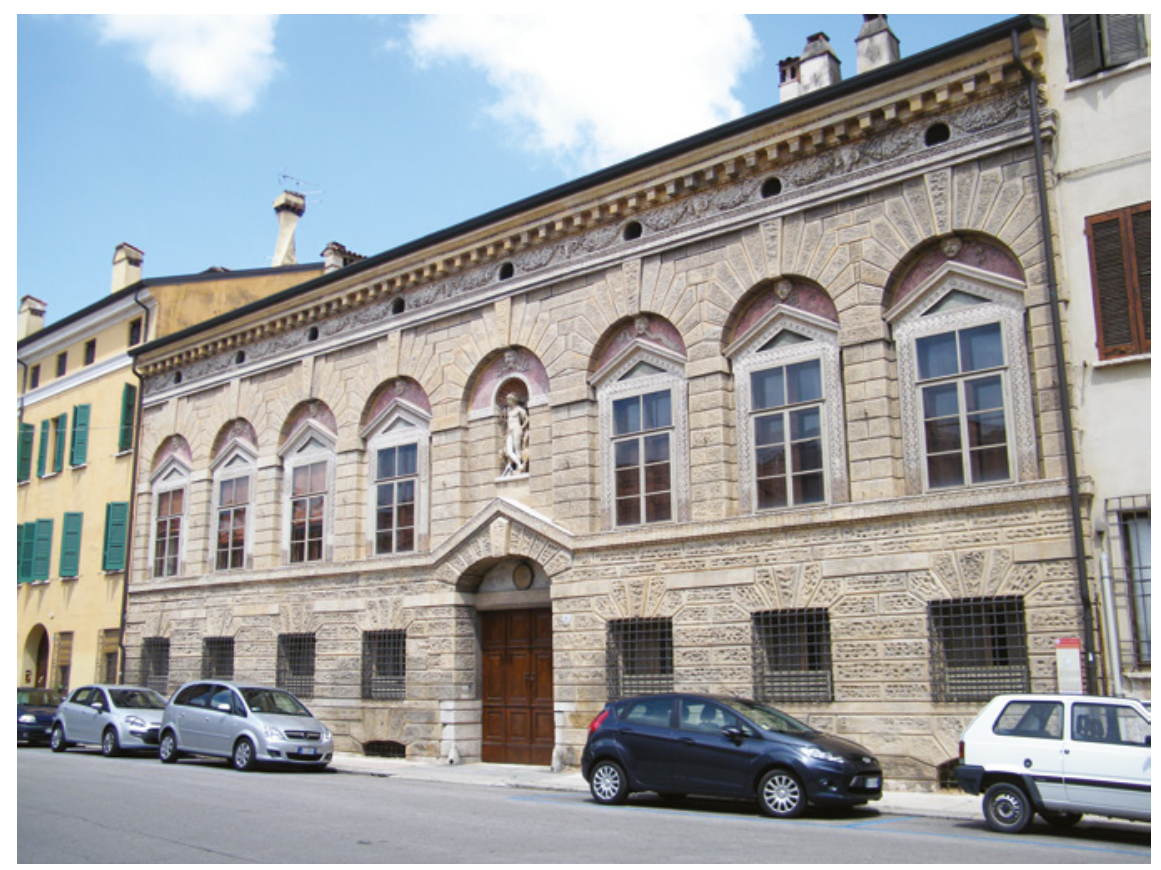

FIGURE 7.4 The house built by Giulio Romano for himself in Mantua, 1544 .

to see his medals and other antiquities. Afterwards he appears to have praised the house — at that time still under construction—as the most beautiful house in Vienna, reason why the Emperor himself also went to see it. ${ }^{7}$ We know this because Strada boasted of it to his Venetian rival Niccolò Stopio, and also on other occasions Strada vaunted his house in letters to his patrons, but there he described its contents rather than its architecture.

Certainly it seems to have been a quite prestigious house. In a letter of recommendation for Strada to the Elector of Saxony of 1576 , the humanist Hubert

7 DOC. 1565-08-26: Luigi Rogna describes the reception accorded at the Imperial court to $\mathrm{Al}$ fonso II d'Este, Duke of Ferrara, to the Castellano of Mantua, Vienna 26 August 1565: 'Fu accompagnata sua eccellenza fin alla porta del suo allogiamento in castello, che fu lo appartamento dove stava sua maestà quando era re dei romani, vivendo ancora la maestà del padre $<$... $>$ Alle volte è andata a vedere le medaglie et l'altre antichità del Strada mantovano, in casa del quale, dallo appartamento sudetto, si va per una via coperta sopra un baglione et sopra il terraglio della città<...>'; Niccolò Stopio to Hans Jakob Fugger, Venice 7 Sept. 1567: '<...>non li [= Strada] mancha modo di riuscirne con bon utile, et certo bisogna bene che così sia, volendo fabricare palazzi de 7 o 8 mila taleri, come dice che lui fa, et che dal duca di Ferrara fu giudicata il più bello di Vienna, onde Sua Maesta Cesarea l'andò anche a vederlo, havendo ciò inteso dal Duca<...>' [BHStA-LA 4852, f. 64/58]. 
Languet says that he often visited Strada's house, which had been built according to the rules of classical architecture, and to such effect that Languet could not name another house in that city of similar elegance and provided with so many features conducive to commodious living. ${ }^{8}$ Strada, who probably inspired Languet's panegyric, himself offered the use of his house to the Duke of Mantua in similar terms:

I offer my house to Your Excellency at any occasion he might need it, which, once its construction is finished, is a suitable lodging for a prince. ${ }^{9}$

At a later date, when Strada encountered financial troubles, he indeed proposed it as a suitable residence for a prince, the young Duke Ferdinand of Bavaria, should he wish to spend some time at the Imperial court. That offer was not accepted, but on another occasion the Count Palatine Georg Johann I of Veldenz-Lützelstein was lodged in Strada's house for some months at the Emperor's expense. ${ }^{10}$ Hans Jakob Fugger himself naturally lodged with Strada when he came to Vienna, as did the Bohemian Magnate Vilém z Rožmberk. In the early 1580 s the top floor of the house was occupied by the Croatian prelate and politician Juraj (György) Drašković (Draskovics), Archbishop of Kalocsa, Ban of Croatia and chancellor of Hungary, together with the offices of the Hungarian chancery for which he was responsible. ${ }^{11}$ Even members of the dynasty occasionally used Strada's house, as in November of 1579, when some courtiers organised a banquet, a dance and a 'mummerey' or masque for the youngest Archdukes: an occasion which indicates that the house included at least one room of sufficient size for such festivities. ${ }^{12}$

8 DOC. 1576-09-07: 'Viennae fui saepius in eius aedibus, quas ad normam veteris architecturae ita aedificavit, ut nesciam, an ullae sint in ea urbe conferendae cum illis elegantia et iis rebus, quae ad commode habitandum sunt necessariae.' Languet probably visited Strada's house in the company of his pupil, Sir Philip Sidney, during his first stay in Vienna in 1573; Sidney, but not Languet, is inscribed in Ottavio Strada's Stammbuch (see below, Ch. 11.1).

9 DOC. $1568-12-28$.

10 Pfalzgraf Georg Johann I. zu Veldenz-Lützelstein (1543-1592); married since 1562 to Anna Maria, daughter of Gustav I Wasa, King of Sweden.

11 DOC. 1577-02-18: [Strada is paid 50 Gulden rent for his house in Vienna] '<...>darin Pfaltsgraf Georg Hans bei Rhein im Jahr 1575 eine Zeit lang gelegen'; Fugger stayed in Strada's house during his stay in Vienna in the winter of 1568; another of Stada's patrons, Vilém z Rožmberka, lodged in Strada's house on his visits to court and knew it well, as appears from Strada attempt to interest him to buy it (DOC. 1573-12-18); on Drašković, cf. DOC. 1581-11-02.

12 DOC. 1579-11-17: Sigmundt von Hochenburg to Archduke Matthias, Vienna 17 November 1579: '<...>Iere Fürstl. Durchl. etc. die fast alle wochen zum ringrennen haben vor ein zehen Tagen in einn Ringrennen zwo Parteyen in deren Jeder sechs waren gemacht vnd also 
A house like that cost quite a lot: in 1567 , when it was still far from finished, Strada boasted to Stopio of having spent seven- to eight-thousand talleri or thaler, and it is clear that this taxed his financial potential to the limits. His financial troubles in the 1570 s doubtless were caused in part by the huge expense of the house itself and of the aristocratic and sumptuous lifestyle it required. When he tried to sell it to Vilém z Rožmberk in 1573, he asked for 'acht dausent Daller, wie wol es mich mer den neyne gekost hatt'; three years later he claimed that it had cost him over ten thousand Thaler, and in 1581 the amount he mentioned was even over twelve thousand Thaler. ${ }^{13}$ This is a huge sum in relation to Strada's annual salary of three hundred Gulden, and makes it quite clear that his salary was only a minor part of his income-the payments he received from Hans Jakob Fugger and later from Duke Albrecht $v$ of Bavaria of the nine to ten thousand numismatic drawings of his Magnum ac novum opus, at a Thaler a piece, come closer to explain Strada's ability to finance a project of this sort. His position as Imperial Architect, however, must directly or indirectly have facilitated the construction of his house. Occasionally he was granted building materials from the Imperial works, and he may likewise have been allowed to use some of its infrastructure, such as scaffolding and machinery. ${ }^{14}$ Thanks to his position he had direct access to the available specialized labour forces, and at least some of his immediate colleagues - the architects and master-masons he worked with at court—will have exchanged their expertise on structural and technical aspects for his artistic advice and access to the relevant materials in his collections.

a discretion es was gelten soll gerendt, als nun Irer Fürstl. Durchl. Parthey soliches gewunnen, haben sich die Sechs als herr von Thurn von Hoyos Jägermeister Teuffel von Zelting vnd von Khünigsperg mit einander verglichen, Iren Fürstl. Durchl. etc. ein Pangöth vnnd Tanz zehalten, haben also ein gar stetlich Pangöth zuberait Ier Fürstl. Durchl. etc. vnd vier Taffel Frawen vnd Junckhfrawen darauf geladen die auch khumben vnd nach dem nachtmal biss auf halbe ainss in die nacht getanzet, auch ein schöne Mumerey die beiden Irer Durchl. etc. Mumschanz gebracht gehalten worden, Ier Durchl. etc. sein zwar gar lustig vnnd frölich gewesen, vnnd ist soliches Pangöth vnd Tanz in des Sträda hauss gehalten worden $<\ldots . .>$.

13 Stopio to Fugger, Venice 5 Sept. 1567 , BHStA-LA 4852, f. 63/57: 'Il Strada è partito 3 dì sono per Mantua <...>Iddio li dia bon viagio, andando a questo modo a spese d'altri a fare fatti suoi, si puo fabbricare delli palazzi, come si è vantato qui di haverne fatto una in Vienna ove ha speso $6 \mathrm{~m}$. taleri, et per compire ne spendera altri 2 o 3.'; DOCS: 1573-12-18; 1576-o616; 1576-09-00; 1581-11-02.

14 In July 1564 Strada was conceded wood for use in the construction of his house; in February 1569 a similar request for lime, by this time probably to be used for plaster rather than for mortar ( DOCS. 1564-07-08; 1564-07-11; 1569-02-00). 


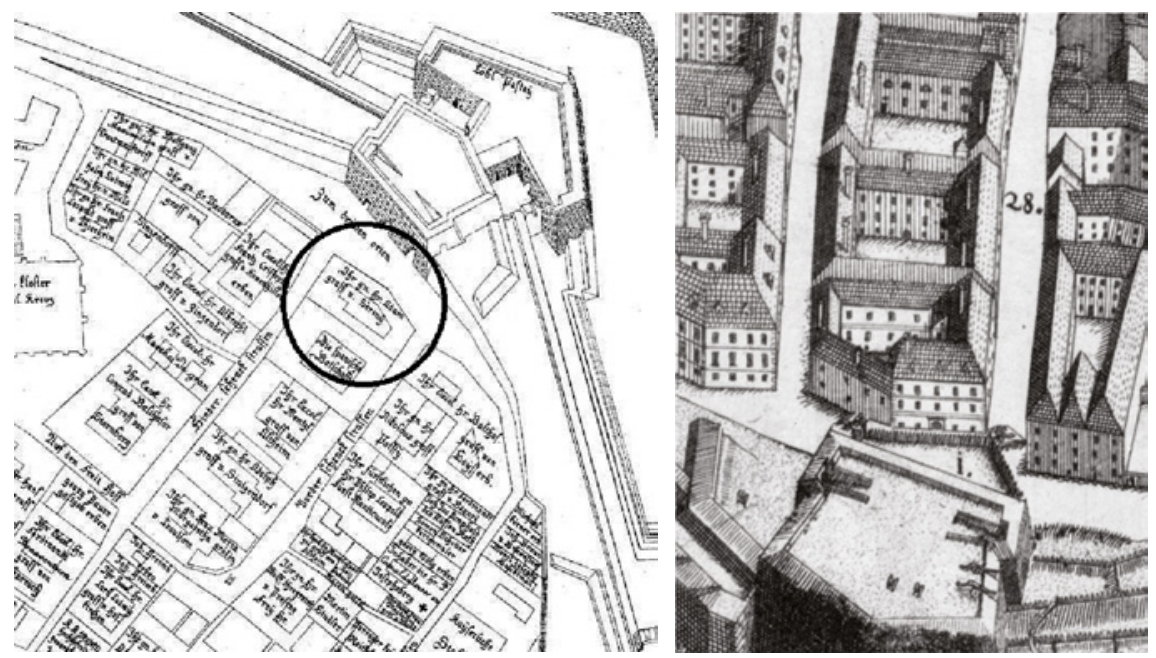

FIGURE 7.5 Daniel Suttinger, town plan of Vienna at the time of the second Turkish siege, 1683, detail.

FIGURE 7.6 Daniel Suttinger, bird's eye view of Vienna during the 1683 siege, detail.

Strada had consciously modelled his house upon the palazzi of his native country, telling his old friend Jacopo Dani, secretary of the Grand duke of Tuscany, that he hoped to show a Florentine visitor 'la mia casa, la quale puol star al pari di una di $\mathrm{q}<\mathrm{u}>$ elle belle d'Italia'. In the eyes both of Duke Alfonso of Ferrara and of the humanist Languet, the Italian, classical manner of Strada's house distinguished it favourably from other Vienna dwellings in a less advanced or vernacular style. It was intended as a sample of up-to-date, Italian, cosmopolitan architecture: a conscious, three-dimensional statement of the principles of humanist architecture expressed in the designs and writings collected in Strada's studio, and an attempt to propagate these in his second fatherland. It is therefore unfortunate that the house, that had largely survived, was demolished in the context of the construction of the Ringstrasse, the ample new boulevard that was planned to circle the inner city after demolition of the Vienna fortifications around 1860 [Fig. 7.3]. Unfortunately the significance of the house was not remarked at the time, so no documentation appears to have been made of it before its destruction. Yet careful examination of the older topographic images that have survived does allow a tentative description and partial reconstruction of the building.

The only more or less factual description of the building is a brief mention in a letter from Hans Jakob Fugger to Niccolò Stopio, of 6 December 1567: 

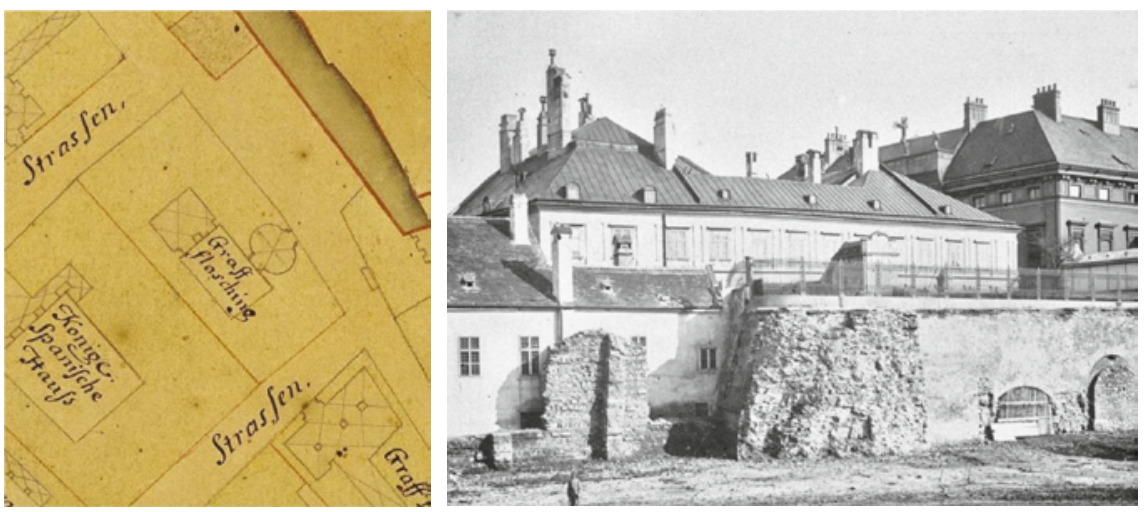

FIGURE 7.7 Werner Arnold Steinhausen, plan of Vienna, 1710, detail.

FIGURE 7.8 Photograph of the former Strada house, shortly before its demolition.

In Vienna I have seen his house, which is as yet unfinished and consists of two wings ['truoti'], and the Lord knows when he will finish it, having begun first with a facade in the Italian manner; it stands in a retired spot within the city walls.' ${ }^{15}$

So Strada's house was located within the city walls in a backwater, a description which fits its location, at the end of street which was a cul-de-sac, closed of by the huge bulk of the Löwelbastei. The site of the house fronted on three sides towards the streets, the Vordere and the Hintere Schenkenstrasse and the narrow cross-street which connected these two, which ran along the inside of the huge bastion. ${ }^{16}$ The word 'truoti', which does not exist in Italian, is most likely a Germanism from the word 'Trakt', the wing of a building, which would indicate that at that time Strada's house consisted of two wings. The principal part of the house was built on top of vaulted cellars, doubtless at least in part relics from the earlier house on the site, and in addition Strada disposed of some workshops in a neighbouring building, where he had restored the antiquities he had acquired in Venice on behalf of the Duke of Bavaria under his own immediate supervision. ${ }^{17}$

15 DOC. 1567-12-06: 'Io ho visto in Vienna casa sua non finita di duoi truoti, et Iddio sa quando la finira poi esser principiata duna facciata alla italiana et sta dentro i muri, in loco ritirato<...>'

16 In Wolmut's town plan of 1547 the house stretches all the way to the Bastei, but in $155^{\circ}$ part of this had been expropriated and torn down for improvements to the bastion, and doubtless also to allow an uninterrupted communication along the inside of the townwalls (Harrer 1957, VII, pp. 196-198).

17 Strada to Hans Jakob Fugger, Vienna, 1 March 1574 (DOC. 1574-03-01). 
From the description of the dinner party and dance organized for the young Archdukes, cited above, we know the house contained at least one large hall or Saal. Its ample size is also indicated in Strada's offer of the house for use by Ferdinand of Bavaria, where he described it as having 'xii stufe con tutte le altre commodità che si puole immaginare', that is twelve rooms heated by the traditional tiled stoves we have already seen in the Grosse Taflstube of the Hofburg [Fig. 5.71]. In view of its size - containing at least two wings of a piano nobile and a top floor, and workshops on the ground-floor-it is unlikely that on Daniel Suttinger's plan of Vienna at the time of the second Turkish siege it had been 'incorporated in a larger aristocratic palace', as Renate von Busch suspected; if only because on that site no really large palace, such as the Stadtpalais Liechtenstein opposite, was ever constructed [Fig. 7.9]. In a bird's eye view of Vienna during the 1683 siege, likewise by Suttinger, the house is recognisable in some detail: at that time it belonged to Count Adám Zrínyi [Fig. 7.6], and consisted of two wings at right angles to one another on the corner of the Vorderen Schenkenstrasse and the Löwelbastei. These are the 'duoi truoti' to which Fugger referred. They consisted of two principal floors over a ground floor, and had an entrance in the centre of the facade on the Löwelbastei.

Part of the plot, on the corner of the Löwelbastei and the Hinteren Schenkenstrasse, was occupied by two buildings, again of two floors, but of lesser height and depth. It is difficult to say whether this subsidiary part already existed in this form in Strada's time. Towards the neighbouring house the courtyard was limited by a long, narrow wing, which seems to be as high as the main block but, being narrow, is covered by a much lower roof. This plausibly could have housed a modest gallery on the level of the piano nobile.

Around 1700 the house had passed to Maximilian Ernst von Wlaschim (Vlašim), who had it reconstructed: he doubled the size of the lower section on the Hinteren Schenkenstrasse, had it run up to the same height and had its facades adapted to those of the principal section. Here he moreover created a new, wider entrance with a porte cochère of a typically baroque plan. This new situation can be seen in Steinhausen's plan of Vienna of 1710, which roughly indicates existing arcades and vaulted vestibules [Fig. 7.7]. In the middle of the eighteenth century it was acquired by Fürst Palm, who adapted the house and its immediate neighbours somewhat to his newly acquired status. As Palais Palm the complex played a certain role during the Congress of Vienna, as the temporary residence of two of the leading ladies during that concourse of Kings and Ministers, Wilhelmine Duchess of Sagan and Princess Catherine Bagration, both at different times mistresses of Metternich, while Princess Bagration functioned as hostess for Czar Alexander I: a story amusingly told in 
Adam Zamoysky' monograph on the Vienna Congress. ${ }^{18}$ Doubtless the house was internally redecorated and restructured by its later owners, but its basic structure probably did not change very much since Wlaschim's interventions, and a photograph taken shortly before its demolition gives some impression of the results [Fig. 7.8$]^{19}$

When it was built Strada's house may have made quite a splash, but by this time it must have struck a very modest figure among the huge baroque palaces built by Fischer von Erlach and Lucas von Hildebrandt, many of which were illustrated in the Wahrhaffte und genaue Abbildung Aller Kirchen und Cloester der Keysserl: Burg und anderer Fuerstl. und Graeffl: Pallaeste<...>der Keysserl: Residenz-Statt Wien, a print series by Ioannes Corvinus after designs by Salomon Kleiner issued in five volumes between 1724 and 1737. Perhaps Kleiner included the Strada house in his view of the Liechtenstein palace opposite merely as a repoussoir, a foil to set off the greater splendour of Domenico Martinelli's masterpiece [Fig. 7.9].

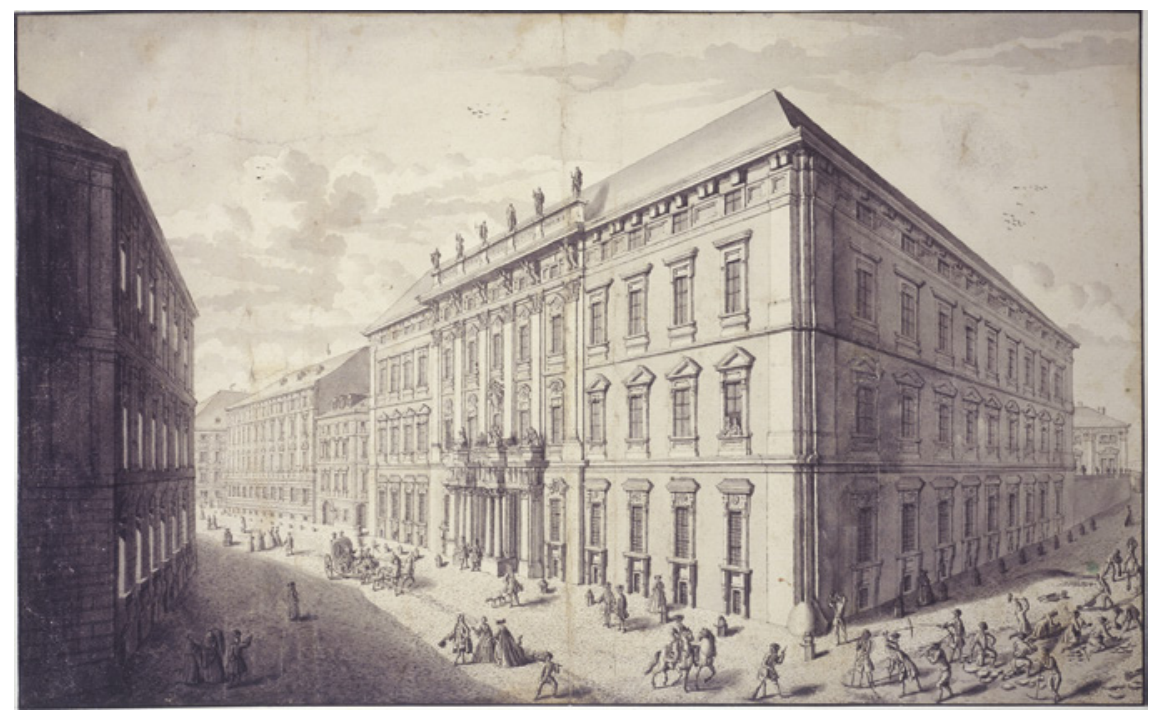

FIGURE 7.9 The former Strada house on the left, in Salomon Kleiner's view of the Stadtpalais Liechtenstein in the Schenkenstrasse, engraving, 1725; Vienna., Österreichische Nationalbibliothek.

18 Zamoysky 2007, pp. 258 and passim.

19 Steinhausen's plan 1710, in ÖNB, Kartensammlung AB 7 A 56, Blatt 17. The photograph should be used with caution, for the roofs may well have been refashioned after damage received in the siege by the Turks in 1683 , when the brunt of the attack fell on the section of wall between Burgbastei and Löwelbastei. 
Nevertheless he took a lot of trouble to illustrate the house in detail, either because he hoped he thus could sell another copy of his print series to its proprietor, or because he recognized its unusual design. He had to practice some pictorial licence to show its facade on the Schenkenstrasse, in reality parallel to the facade of the Palais Liechtenstein; for compositional reasons he also changed its proportions, making the house almost as high as the Liechtenstein palace itself, while in reality it was rather lower [cf. Fig. 7.8]. Given that the house is thus used merely as a frame for the more important palace, and is shown in extreme foreshortening, it is remarkable how much care Kleiner took to reproduce its architectural design: an indication that the print can be used as a reliable source for the appearance of the facade at that time.

This is even more notable in Kleiner's original drawing, preserved in the Österreichische Nationalbibliothek [Figs. 7.9 and 7.11]. ${ }^{20}$ Because of its extreme foreshortening this is difficult to read, but nevertheless it shows sufficient detail to get a very good idea of what the architecture looked like. This is supplemented and corrected by Kleiner's drawing of the neighbouring palace of countess Althan-Pignatelli: here the baroque palace is framed by narrow strips of the facades of the neighbouring houses, both originally built in the 156os, by Christoph von Teuffenbach on the right, and by Jacopo Strada on the left hand side [Fig. 7.12]. ${ }^{21}$

From these two images it appears that in 1725 the house had a strictly classical facade of three stories: two stories articulated by very flat coupled pilasters over a rustic story of bossed masonry articulated by blind arcades filled with windows carried on brackets. As in the Stallburg courtyard, the orders are extremely simplified and undefined, and here the entablatures are incomplete, that of the first floor lacking its cornice, that of the second floor lacking its frieze. On the basis of the drawings Mario Carpo has prepared a tentative reconstruction of the facade on the Vordere Schenkenstrasse [Figs. 7.13 and 7.10 (detail) $].{ }^{22}$ From this it is evident that this cannot be a facade conceived in the Vienna of the Baroque. Its close relationship with Roman palace architecture

20 ÖNB-Hs, Cod. $\min .9$, Bd. 1, f. 12

21 ÖNB-Hs, Cod.min. 9, Bd 1, f. 14. The facade of the Teuffenbach house was later remodelled, and it is this baroque version that is visible in the print; but its structure still largely dates back to the 1560 s, cf. Buchinger / Mitchell / Schön 2006.

22 The reconstruction was made in close consultation as an illustration to a paper read at the Serlio conference in Vicenza in 1987 (Jansen 1989, p. 211, pl. 7) and was republished in Jansen 1988, p. 136, pl. 6, and in Louthan 1997, p. 34, pl. 4. I am very grateful to Dr Carpo for having taken the trouble and for having given me the benefit of his expertise. 

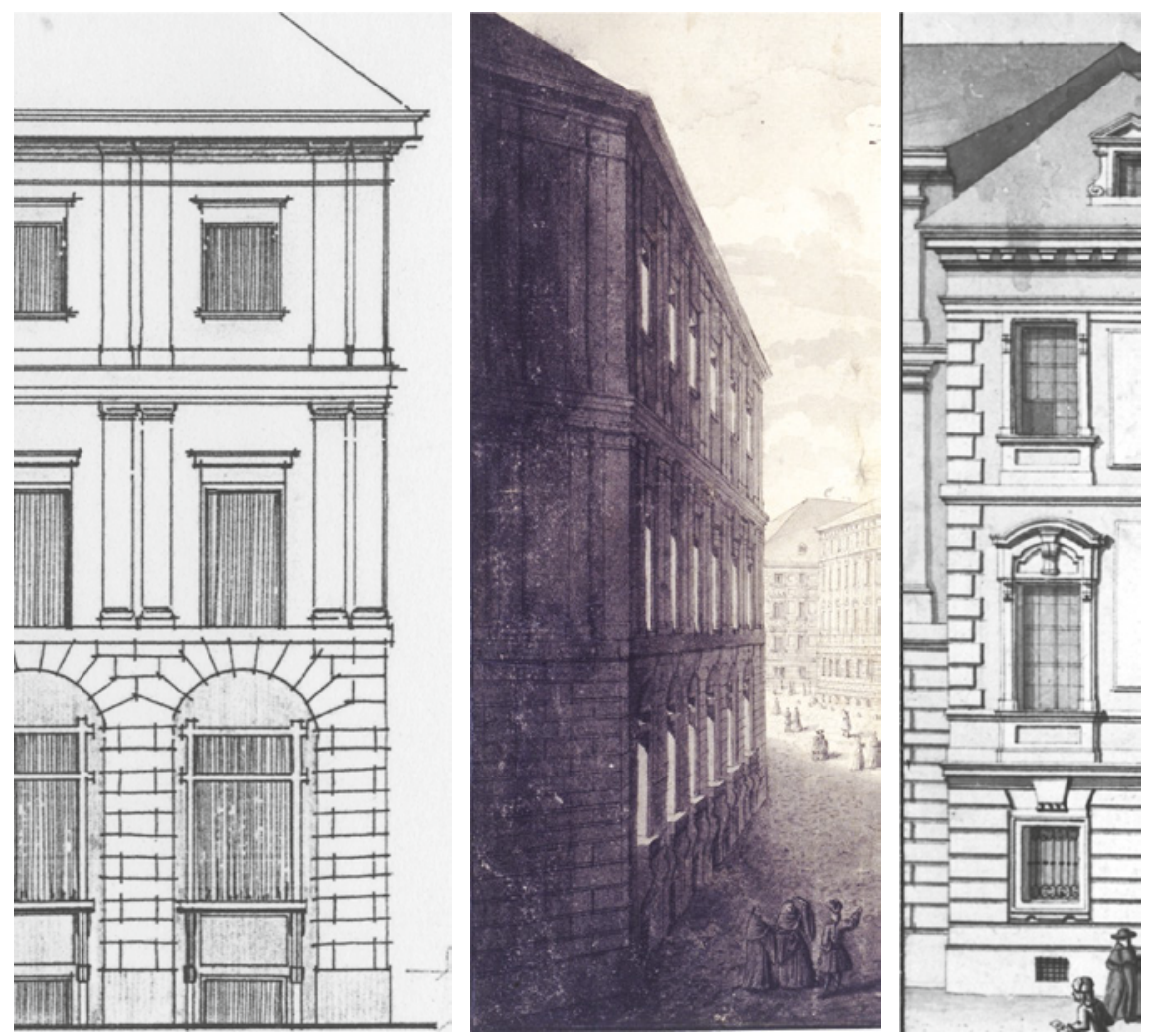

FIGURE 7.10

Mario Carpo, reconstruction of the house of Jacopo Strada in Vienna, detail of fig $7 \cdot 13$.

FIGURES 7.11-7.12 The house of Jacopo Strada in Vienna, details of Salomon Kleiner's views of the Stadtpalais Liechtenstein (centre; detail of Fig. 7.9) and of the Palais Althan-Pignatelli (the strip on the left margin of the print).

of the first half of the sixteenth century warrant the conclusion that the facade in Kleiner's 1725 print is basically that designed and built by Jacopo Strada.

The facade shown in Kleiner's drawing is the side facade, as can be deduced not only from the lack of an entrance-which might have been moved at a later date-but also from the even number of bays. This means that the principal façade including the entrance looked toward the later Löwelstrasse, and immediately faced the huge Löwelbastei. This choice can be explained by the fact that the quickest way from the Hofburg was along the inside of the fortifications: on arrival this was the facade which was first seen and could be best observed. From the description of Duke Alfonso's visit to the house, moreover, we know that it could be reached from the Hofburg along a covered passage on top of the fortifications, the exit of which must have been inside 


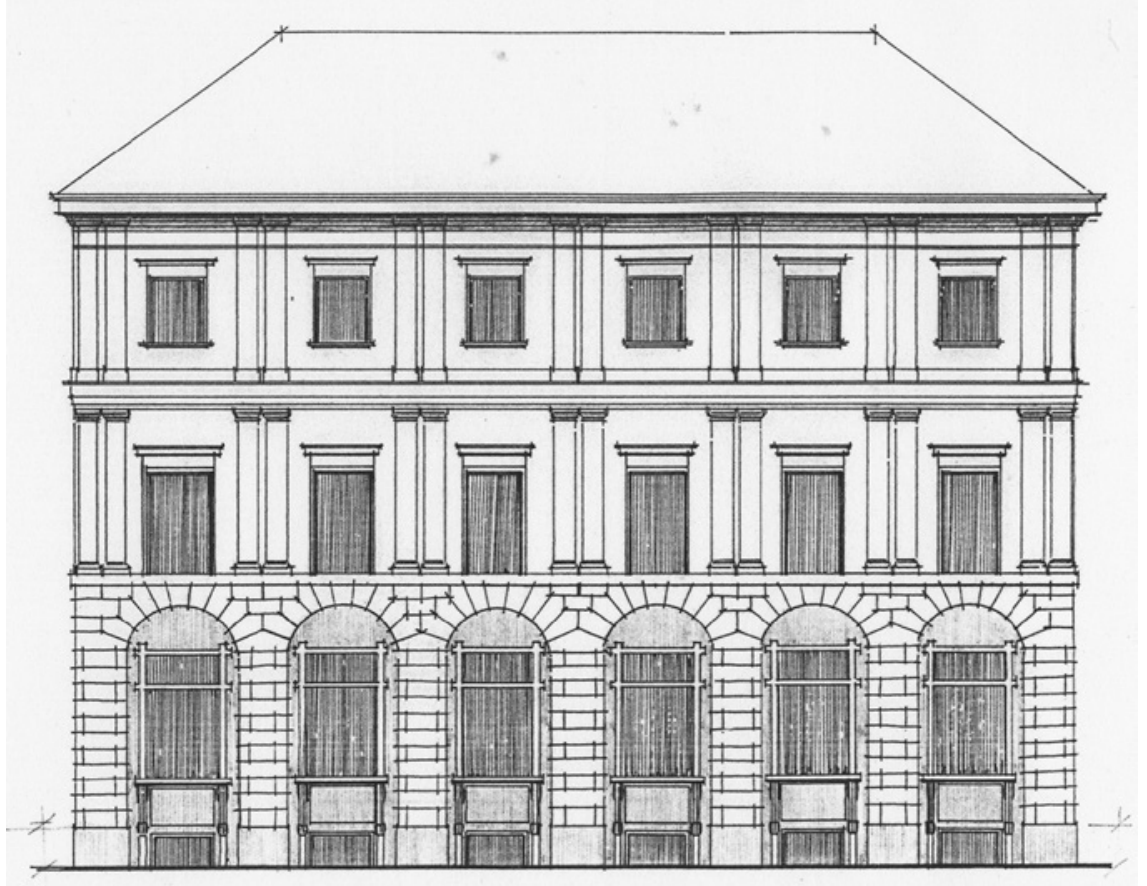

FIGURE 7.13 Mario Carpo, reconstruction of the house of Jacopo Strada in Vienna, facade on the Vordere Schenkenstrase.

the Löwelbastei, that is exactly in front of the entrance of Strada's house. ${ }^{23}$ Naturally its principal facade was that which was not only the best visible from this passage on top of the ramparts, but also was the side from which Strada's august patron would approach it.

The articulation of this entrance facade continued that of the side facade, but its corners where stressed by slightly more narrow, windowless bays framed by coupled pilasters. This is visible both in the Kleiner drawing and in the nineteenth century photographs [Figs.7.11 and 7.8]. Doubtless the entrance

23 DOC. 1565-05-26: 'Altre volte è andata a veder le medaglie et l'altre anticaglie del Strada Mantovano, in casa del quale dallo appartamento sudetto [that in which Alfonso was lodged] si va per una via coperta, sopra un bastion in sopra il Terraglio della città.' I do not know whether the existence of this passage is documented elsewhere; certainly the use of the top of the ramparts as a promenade where the Emperor and his immediate entourage could take their daily exercise in reasonable privacy is rather likely; a covered passage would allow this even in bad weather (being on top of the fortifications, it can hardly refer to a 'covered way' in the military sense). 

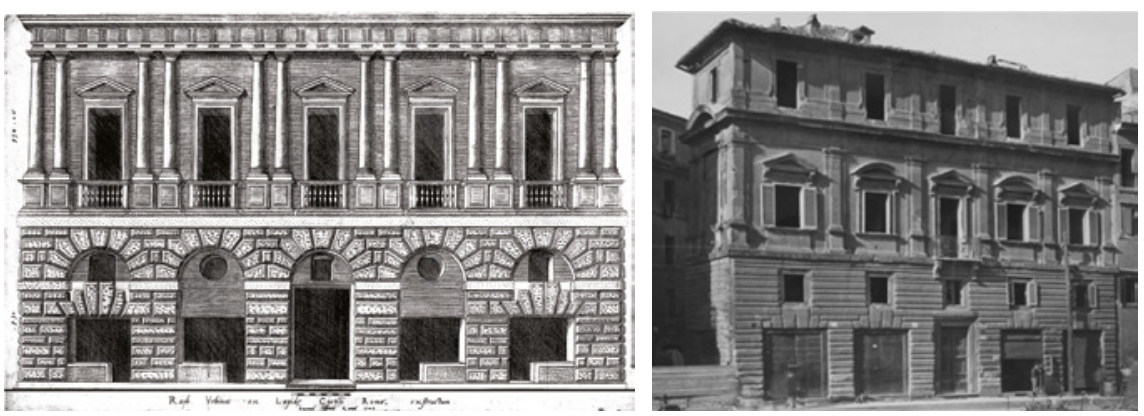

FIGURE 7.14 Donato Bramante, Palazzo Caprini, Rome; ca 1510, from 1517 inhabited by Raphael; engraving by Antonio Lafréry, 1549 .

FIGURE 7.15 Attributed to Raphael, house for Jacopo da Brescia, Rome; ca 1515-1519 (demolished ca 1936).

was placed in the centre of this facade, and it opened probably into the crossvaulted loggia that can be seen on the Steinhausen plan [Fig. 7.7]. These data would allow a very tentative, ideal reconstruction of the principal part of Strada's house as he may have planned it, but for lack of further visual evidence that is rather too speculative to be attempted here.

The general type of Strada's house is Bramante's very influential Palazzo Caprini, built ca 1510 and since 1517 inhabited by Raphael [Fig. 7.14]: a rustic story articulated by arches, carrying a piano nobile articulated by coupled Doric semi-columns; or the similar house built for Jacopo da Brescia, physician to Pope Leo X, between 1515 and 1519, probably after a design by Raphael himself, where the coupled semi-columns have been replaced by superimposed pilasters [Fig. 7.15]. ${ }^{24}$ A very similar type of palace is included in Serlio's Settimo Libro. It is the first of a series of proposals for townhouses, and is described as 'una habitatione, per far dentro alla Città in luogo nobile': a qualification which also holds for Strada's house, as we have seen [Fig. 7.16]. ${ }^{25}$

In most of these examples the facades are articulated by an order of half columns, and all top these with a complete entablature, giving them a plastic and monumental appearance. Kleiner's drawing, on the other hand, shows that the facade of Strada's house was decorated by the shallowest type of rustica on

24 The Palazzo Caprini was demolished in the seventeenth century. A very similar solution is found in the still existing Palazzo Vidoni-Caffarelli, designed by a pupil of Raphael, probably Lorenzo Lotti, Giulio Romano's brother-in-law.

25 The 'botteghe', the small shops or workshops peculiar for Roman palaces, lack in Strada's house; these were unusual in Vienna, and would have impeded good lighting in the huge cellars over which most Viennese dwellings, including Strada's, were built. Moreover they would hardly have been functional. 


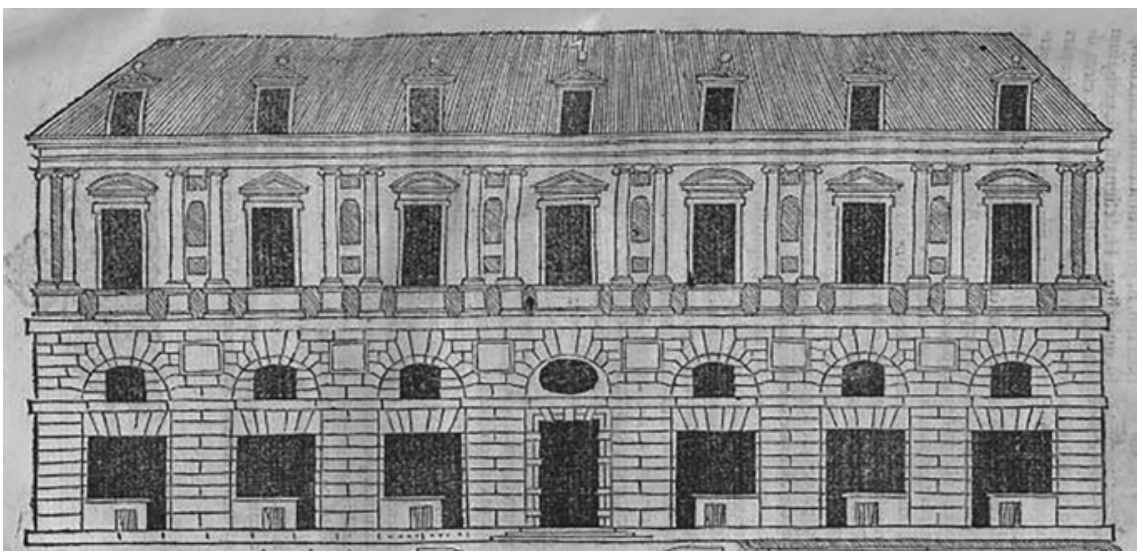

FIGURE 7.16 Serlio, design for a townhouse on a 'noble' location, from Strada's edition of the Settimo Libro, 1575 .

the ground level, and an order of the flattest of pilasters on piano nobile and top floor. Moreover these orders are topped by entablatures that are incomplete: that of the piano nobile lacks its cornice and that of on the top floor its frieze, and there the capitals are integrated in the architrave. Even more than the courtyard of the Stallburg this 'abbreviated' order recalls Roman palaces designed by Raphael and his school, in particular the Palazzo AlberiniCicciaporci (ca 1517-1519, Raphael, assisted by Giulio Romano) [Fig. 7.16] and Giulio Romano's Palazzo Stati-Maccarani (ca 1522-1525) [Fig. 7.17].

Strada's dependence on the example of his earliest and most admired master was a conscious choice. He pointedly wished to present an antithesis to local traditions, an alternative based on the examples constructed by the rulers of the Roman Empire, whose history and works he had studied so assiduously, and whose direct successor he was so proud to serve. These examples included also those works produced in his native country under the immediate influence of the renewed study of Antiquity, some of which equalled or even surpassed those of the Ancients, such as those of Raphael and Giulio.

It remains unclear why-among the options he had even within Giulio's oeuvre-Strada opted for a restrained style the intellectual sophistication of which can hardly have been appreciated by his Vienna contemporaries, instead of for a more immediately spectacular, more robust manner for which he could find examples among the works of Michelangelo, Sansovino, Palladio or Sanmicheli. It may have been merely a question of taste: he may have preferred its refined elegance. But possibly his preference for simplicity and sobriety in architecture-which seems to conflict with other aspects of his personality as we know it from, for instance, the Titian portrait—indicates that he shared the 

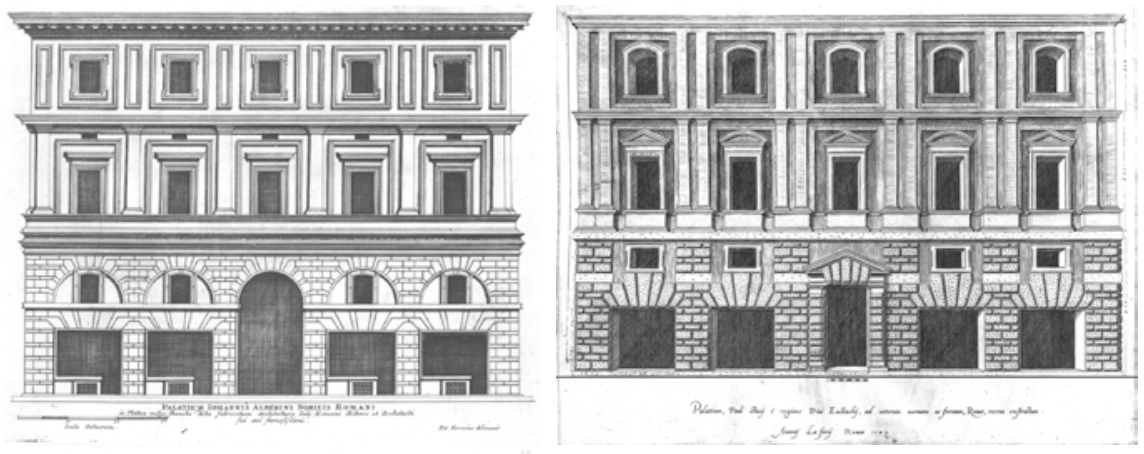

FIGURE 7.17 Raphael, assisted by Giulio Romano, Palazzo Alberini-Cicciaporci, Rome ca 1517-1519.

FIGURE 7.18 Giulio Romano, Palazzo Stati-Maccarani, Rome, ca 1522-1525, engraving by Lafréry, $155^{\circ}$.

ideological motives that research of the last three decades has rediscovered in Serlio's writings and in some of his executed works, ideas which may have been particularly congenial also to Strada's patron, Maximilian II. However, a discussion of these would transcend the limits of this study, and remain inconclusive for lack of direct evidence. ${ }^{26}$

26 Manfredo Tafuri first discussed the evangelical bias in Serlio's treatise (Tafuri 1985, pp. 101-112; Tafuri 1987), and it has since been treated a.o. in Mario Carpo's La maschera e il modello: Teoria architettonica ed evangelismo nell' Extraordinario Libro di Sebastiano Serlio (Carpo 1993; cf. Carpo 1992). The possible philosophical and ideological significance of classical architecture in the Renaissance is an important topic in the history and theory of architecture, e.g. Rudolf Wittkower's Architectural Principles in the Age of Humanism (1949), John Onians' Bearers of Meaning: Classical orders in Antiquity, the Middle Ages and the Renaissance (1990), and the work of Joseph Rykwert and many others. Strada may wel have shared some of these ideas: though on the surface he always remained a Roman Catholic, he was in contact with many Protestants and may have had some sympathy for the Reformation. For a brief discussion of his position, see below, Ch. 11.5. 